DOI: https://doi.org/10.24144/2409-6857.2019.1(53).27-33

УДК 303.7:378.1

Липов В.В., Чернуха Т.С.

\title{
КОМПАРАТИВНИЙ АНАЛІЗ В ДОСЛІДЖЕННІ СИСТЕМ ВИЩОЇ ОСВІТИ
}

\begin{abstract}
У статті проаналізовано історію та представлено загальний аналіз компаративного методу досліджень. Розкрито теоретичні основи компаративного інституціонального аналізу. Проаналізовано праці в яких розглядається компаративний аналіз економічних систем, в тому числі й освітніх. Виділено i розглянуто найбільш розповсюджені напрямки компаративного аналізу систем вищої освіти. Врахування комплементарної зумовленості елементів соціально-економічних систем дозволило визначити загальне, одиничне та особливе у їхньому інституціональному устрої.
\end{abstract}

Ключові слова: вища освіта, економічні системи, інституціональні елементи, інституціональна система, компаративний аналіз, соціально-економічні моделі.

Постановка проблеми. В умовах реформування вищої освіти (ВО) в Україні особливого значення набуває дослідження досвіду запозичення систем організації ВО інших країн. Оскільки система ВО є елементом більш широкої інституціональної системи країн в цілому, то вона передбачає розуміння передумов появи саме комплементарних елементів систем і відповідне розуміння можливостей їх впровадження в український освітній простір. Компаративний аналіз можна вважати одним 3 дієвих способів визначення можливостей такого запозичення елементів інституціональної системи ВО.

Аналіз останніх досліджень і публікацій. Значний внесок формування методологічних засад інституціонального компаративного аналізу закладено в роботах таких вчених, як Р. Коуз, А. Грейф. Серед перших, хто почав застосовувати цей метод у своїх роботах були Р. Нурєєв, А. Пилясов, А. Тихонов, Ю. Ясинський. Практичне застосування інституціонального компаративного аналізу ми знаходимо у дослідженнях С. Фрейвальда, В. Липова.

Особливого значення набувають праці, в яких розглядається компаративний аналіз економічних систем. До таких можна віднести роботи О. Ананьїна, А. Бузгаліна та А. Колганова, А. Кредисова, Ю. Ольсевича, В. Липова, Г. Сорвиної, тощо. Так О. Ананьїн пропонує

(C) Липов В.В., доктор економічних наук, професор кафедри міжнародної економіки та менеджменту ЗЕД Харківського національного економічного університету імені Семена Кузнеця. Тел. 050-880-27-17, e-mail: Lypov_vl@ukr.net

Чернуха T.C., аспірантка кафедри міжнародної економіки та менеджменту ЗЕД Харківського національного економічного університету імені Семена Кузнеця. Тел. 050-040-00-09, e-mail: Tatyana0009@gmail.com поєднати в процесі економічних досліджень інституціональний порівняльний підхід М. Аокі, як такий, що «переважно вирішує дескриптивні завдання», «метод наукового пояснення певних історичних ситуацій» на основі розробок запропонованих А. Грейфом та теорію регуляції, визначальний внесок у розвиток якої вніс Р. Буайє. Такий широкий спектр досліджень, в тому числі колективні наукові роботи А. Бузгаліна та А. Колганова, об'єднує об'єкт дослідження - економічні системи.

Формулювання цілей статті. На підставі поглибленого аналізу теоретичних засад компаративного аналізу визначити дієві інструменти та методи, які можна запозичити 3 інших інституційних структур систем ВО за допомогою компаративного аналізу.

Опис основного матеріалу дослідження. Звернення до компаративних методів дослідження економічних систем дозволяє застосувати існуючі напрацювання в аналізі інституціональних елементів освітньої галузі. Методологічні основи порівняльного аналізу сконцентровано на забезпеченні виявлення характеру зв'язків, закономірностей взаємодії таких складових інституціональної ієрархії, як цінності, інституції, інститути, інституціональні комплекси (інституціональні блоки, базові інститути) соціально-економічних систем (CEC) в цілому. Система ВО $є$ частиною інституціональних комплексів та СEC.

Проаналізуємо історію та зробимо загальний аналіз компаративного методу. Термін «компаративістика» походить від латинського слова «соmparer», що означає «порівнювати». В процесі компаративних досліджень виникає питання про можливість порівняння досліджуваних елементів. Проте такі науковці, як Дж. Мілль, Р. Макридис стверджували, що кроснаціональне дослідження можливе, коли 
порівнюють країни, які схожі або протилежні за деякими спільними критеріями. Метою компаративного аналізу є виявлення специфічних особливостей порівнюваних елементів систем, і відповідне пояснення таких відмінностей. Е. Дюркгейм вважав, що компаративний аналіз представляє собою зіставлення об'єктів для виявлення подібності та відмінності, передумов і наслідків, динаміки та природи перетворень [1]. Результатом компаративного аналізу є отримання уявлення про наявність або відсутність специфічних закономірностей в розвитку досліджуваних інституціональних об'єктів (елементів системи).

Як зазначає Л. Гук, компаративні дослідження покликані забезпечити комплексне вивчення інституціональної системи, як «внутрішньо диференційованої, змінної системи, взаємопов'язаної з різними аспектами культури й суспільства певного народу» [2, с. 35]. Компаративний метод, шляхом зіставлення, дозволяє виявити загальне та особливе в різноманітті явищ. За твердженням I. Соколової, компаративний аналіз - метод наукового дослідження, що має результатом встановлення спільних або відмінних особливостей досліджуваних елементів: «Ми порівнюємо явища задля глибшого пізнання системи відношень між ними, які характеризують: тотожність / подібність / відмінність; спільне / особливе / унікальне; універсальне / зональне / локальне; загальнолюдське / інтернаціональне / національне; загальне / особливе / індивідуальне тощо» [3, с. 24]. Основні труднощі застосування даного методу пов'язані 3 необхідністю правильного вибору явищ, які будуть зіставлятися, піддаватися науковому спостереженню, опису та теоретичному тлумаченню.

Інституціональний компаративний аналіз стає затребуваним для дослідження специфіки та динаміки процесів. Основи компаративного інституціонального аналізу сформулював $\mathrm{M}$. Аокі, а його широке застосування почалось після публікації праць Д. Норта.

Починаючи 3 середини 90 років акцент компаративних досліджень зміщується в сторону вивчення комплементарних засад визначення інституціонального устрою відмінних СЕС.

Компаративний аналіз економічних систем передбачає визначення загального й особливого. Відповідно критерієм оцінки $є$ співпадіння або відмінність об'єктів порівняння саме у цьому особливому. Оскільки порівнюються однорідні явища, або їх частини, що мають спільні критерії. Тут вступає в дію допущення «за інших рівних».
Комплементарна зумовленість елементів СЕС дозволяє визначити загальне, одиничне та особливе у їхньому інституціональному устрої. Але все одно увагу зосереджено на пошуку особливого та відмінного в СЕС. Результати компаративного аналізу полягають у створенні можливостей прогнозування характеристик інститутів, властивих певним моделям СЕС на основі знання принципу їх функціонування.

Таким чином компаративний аналіз $є$ дієвим інструментом виявлення ефективних форм відтворювального процесу інституціональних систем. Однією з них є система ВО.

Перш за все проаналізуємо роботи вчених, які проводили компаративний аналіз освітніх систем. Компаративний підхід до вивчення освітніх систем висвітлюється в роботі Дж. Ст. Мілля, який порівнював шотландську й англійську системи ВО. До сучасних дослідників компаративного аналізу освітніх систем світу можна віднести Ф. Альтбаха, М. Карного, Б. Кларка. Результати проведення компаративного аналізу специфіки освітніх систем у різних країнах висвітлюються в роботах таких вчених як: Ю. Алферов; П. Бродфуд; Г. Башнянин, О. Свінцов та Т. Панчишин; Г. Кучеренко та О. Мартинюк; Н. Лавриченко; О. Левченко; В. Липов; О. Локшина; Т. Фініков, тощо.

Однак, варто зазначити, що автори використовують різні методологічні підходи до порівняння систем ВО. Переважно компаративний аналіз обмежується описом ключових характеристик i зіставленням кількісних характеристик певних освітніх систем.

Серед найбільш застосованих напрямів компаративного аналізу систем ВО можна виділити наступні: кількісний/якісний компаративний аналіз, графічний компаративний аналіз, інституціональний історичний на основі використання теорії ігор, інституціональний компаративний аналіз.

Кількісний компаративний аналіз систем ВО дозволяє провести оцінку якості системи освіти, яка склалась у певній СЕМ. Визначення якісних показників освітнього простору окремої країни передбачає комплексне оцінювання всіх елементів структури системи освіти. Крім того, якісні характеристики системи ВО окремої країни показують рівень іiї розвиненості. Наприклад, як демонструють результати дослідження, проведеного в Гарвардському університеті, кожен додатковий рік навчання не лише підвищує дохід i продуктивність випускників, а й знижує на певний відсоток показники бідності, злочинності, безробіття, алкоголізму, тощо в країні [4]. В 
американській системі оплата праці громадян 3 ВО в 2,5 рази вище, ніж у громадян 3 середньою освітою [5, с. 14]. Аналіз кількісних показників ВО може продемонструвати якість системи ВО, що в свою чергу має прямий вплив на розвиток країни. Крім того в дослідженні автора компаративний кількісний аналіз наглядно ілюструє якісні характеристики систем ВО [6].

Графічний компаративний інституціональний аналіз передбачає дослідження порівняння елементів інституціональних систем за допомогою малюнків, діаграм, графіків. Досліджуючи їх форму і зміст можна зробити відповідні висновки щодо аналітичних обгрунтувань певних процесів. Це дозволяе наглядно продемонструвати характер, динаміку економічної системи, в тому числі й системи ВО.

Інституціональний історичний аналіз на основі використання ігрового підходу сформулював i активно використовує А. Грейф [7]. Як наголошує вчений, теорія ігор досліджує ситуації, які виявляються стратегічними, а саме пояснюють оптимальну поведінку одного гравця, як реакцію на дії іншого. В свою чергу компаративний аналіз систем ВО з використання теорії ігор дозволяе визначити набір можливих дій та їх наслідків, які виникають в процесі інтерактивної взаємодії учасників. Відповідно, на основі знання особливостей культури певних країн, можна прослідкувати зумовленість еволюції специфічних інституціональних відносин в системах ВО відповідних СЕМ. Так в країнах Перської затоки, які ставлять за завдання створити заклади ВО (ЗВО) світового рівня, здійснюються серйозні перетворення в освітньому просторі. Соціальна спрямованість ціннісної системи тут має виражений егалітарно-колективістський характер. Як свідчать дослідження Маслоу в країнах 3 колективістською культурою студенти не проявляють ініціативу в процесі навчання. До них звертаються, як до колективу, певної групи. Зараз роль диплома тут значно зростає. I такі країни як Єгипет, Саудівська Аравія, Ліван вже мають найбільшу кількість ЗВО серед країн Перської затоки [8]. I, для прикладу, щоб потрапити до ЗВО Єгипту, потрібні відмінні результати вступних іспитів. Диплом педагогічного училища $\epsilon$ пропуском до 3ВО вищої категорії. Навчання $\epsilon$ безкоштовним для всіх громадян таких країн, крім того кожен, хто має відповідний рівень підготовки, може навчатись у будь якому ЗВО світу за рахунок держави, з отриманням соціальної допомоги. Це, в свою чергу, стимулює молоде покоління на навчання [8]. Таким чином забезпечується відповідна реакція на певні передумови створені державою.

Окремі дослідники, наприклад Б. Кларк спираються на інституціональний компаративний аналіз систем ВО. В роботі пропонується використання останнього для дослідження специфіки елементів системи ВО відмінних соціально-економічних моделей (СЕМ). В свою чергу це дозволяє визначити інституціональні елементи, які в найбільшій мірі, за умовами походження, формування, функціонування $\epsilon$ релевантними українському інституціональному контексту. Відповідно вони можуть бути інтегровані, 3 мінімальними зусиллями, в інституціональну систему освіти України та здатні забезпечити зростання ефективності ii функціонування в цілому.

Оскільки система ВО ієрархічно структурована та кожний елемент виконує відведену йому функцію, то для подальших етапів дослідження компаративний інституціональний аналіз можна розділити на два підходи: структурний і функціональний.

Структурний компаративний аналіз почнемо 3 загального огляду системи, а потім деталізуємо. Проведемо аналіз ієрархічної структури за пї рівнями. Відповідно визначимо та охарактеризуємо окремі інституціональні рівні ієрархічної структури системи вищої школи; визначимо та опишемо ключові елементи кожного 3 рівнів та в процесі порівняння основних моделей інституціонального устрою систем ВО визначимо загальне, одиничне та особливе. Функціональний компаративний аналіз передбачає дослідження комплементарних інституціональних функцій цілісного ієрархічного устрою системи ВО. «Принцип цілісності, - на думку В. Липова, - передбачає внутрішню єдність функцій, здійснюваних інституціональною системою, охоплення ними всіх аспектів життєдіяльності системи, необхідних для забезпечення іiї існування» [9, с. 27].

Для комплексного інституціонального компаративного аналізу систем ВО в різних СЕМ, необхідне визначення специфіки розвитку кожного елементу інституціонального устрою системи ВО в різних країнах, зіставлення та аналіз даних про їх функціонування. Ефективність функціонування інституціональної складової систем ВО забезпечується комплементарністю їх елементів. Відповідно трансформація окремих інституцій або інститутів зумовлює необхідність часткових або й повних змін інших іiі складових. Тому інституціональний компаративний аналіз передбачає системний 
підхід охоплення всього комплексу елементів інституціонального устрою системи ВО.

Відправним моментом такого аналізу $\epsilon$ врахування ціннісного підгрунтя національної господарської культури, визначення його взаємозв' язку з базовими інститутами відповідної CEM, конкретними інституціями та інститутами, інституціональними блоками, СЕС та СЕМ в цілому. Специфіка соціальних орієнтацій ціннісних систем зумовлюе прийняття або відторгнення певних інституцій (як норм соціальної взаємодії) або інститутів (як комплексів інституцій, що утворюють ії організаційні форми). У своїй сукупності інституції й інститути формують інституціональні блоки, що забезпечують окремі сфери соціального відтворювального процесу (навчання i підготовка кадрів, виробничі відносини, системи фінансування, тощо). Відповідно зберігається взаємозв'язок між особливостями національних культур та специфікою інституціонального устрою систем BO.

Специфіка інституціонального устрою системи ВО окремих країн відбиває розвиток інституціональної структури освітнього простору відповідних СЕМ. В основу англосаксонської CEM покладено цінності протестантизму, які мають яскраво виражену індивідуалістськоконкурентну спрямованість. Така система цінностей передбачає виражений індивідуалізм. Соціальним виправданням можна вважати турботу кожної особистості про власні потреби та прагнення до самоствердження, самовираження. Прослідковується взаємозв'язок ціннісних орієнтацій на систему ВО в даній CEM. Навчальний процес індивідуалістських країн передбачає, перш за все, розвиток самостійності та впевненості в собі. Студенти охоче проявляють ініціативу до участі в бесіді. В країнах, де сформувався постперехідний капіталізм, ключовий вплив на формування інституціональної моделі справляють релігійні цінності православ'я. В інституціональній сфері має домінуючий вплив коммунітариська спрямованість ціннісної системи. Результатом швидкої перебудови на ринкових засадах стало суперечливе переконання в крайнах 3 постперехідним капіталізмом егалітаноколективісьих (під впливом релігійного православного світогляду) та індивідуалістськоконкурентних ціннісних орієнтацій (в наслідок поспішних перетворень ціннісних орієнтацій). Суперечливе поєднання породжує проблеми в процесі реформування системи ВО. Однак в системах ВО постперехідних країн це вимагає більш прискіпливої уваги до вивчення проблем реформування вищої школи. Однак в освітньому просторі постперехідних країн не створено спеціальних структур яким делеговано повноваження 3 проведення інституціональних досліджень. Вони носять епізодичний характер, виконуються розрізненими підрозділами закладів ВО [10]. Для прикладу в англосаксонській СЕМ сформовані офіси інституціональних досліджень, які відповідають за впровадження, вдосконалення, вивчення ефективності норм, правил, організації навчального процесу (прийом абітурієнтів, створення умов навчання, стратегічне й фінансове планування, акредитацію, оцінку ефективності роботи окремих підрозділів і служб, що відповідають за надання ВО) [11]. В Австралії і Новій Зеландії інституціональні дослідження зосереджені на оцінці якості освіти, процесу навчання, підготовки внутрішньої та зовнішньої звітності [12].

Компаративний аналіз передбачає порівняння процесів, базою яких слугують інформаційні дані. Одним 3 джерел інформації для компаративного дослідження, а саме елементів систем ВО є збір, підготовка й аналіз даних, які свідчать про розвиток закладів ВО й освітнього простору в цілому. Відповідно, такий компаративний інституціональний аналіз грунтується на вивченні широкого кола даних, здобутих шляхом прискіпливого опрацювання інформації, зібраної в різних джерелах. Від якості інституціонального компаративного аналізу даних в кінцевому результаті залежить цінність рекомендацій 3 розвитку освіти у СЕМ i, можливо, конкретного закладу ВО. Такі дані можуть представляти собою внутрішню статистику закладів ВО (викладацький склад; дисципліни, які викладаються; академічну успішність студентів тощо), так і результати міжнародних даних з ВО (за кількістю зарахованих у заклади ВО студентів різних країн, де простежується деякий проміжок часу; показниками мобільності студентів (відсоток студентів 3-за кордону або тих, що виїжджають на навчання до інших країн); дані, щодо відсотка людей з ВО в конкретній країні; щодо відсотка населення охопленого ВО в певній віковій кагорті; тощо).

3 методологічної точки зору для інституціональних компаративних досліджень систем ВО різних країн, доречні два питання.

1. За яким критерієм обрати країни для порівняння інституціонального устрою систем ВО в різних СЕM?

2. Які вимоги висуваються до інструментарію компаративних інституціональних дослідженнях систем ВО, а 
саме їх елементів?

Питання вибору країн для компаративного аналізу систем ВО є одним з головних. Бо саме від обраних країн залежатиме дієвість результатів і якість рекомендацій. Безперечно, компаративні дослідження досить поширені, але до методологічних рекомендації для такого аналізу не завжди приділяється належна увага. Відмітимо, що об'єктом для порівняння можуть слугувати не лише статистичні, що характеризують різні аспекти систем ВО, але й економічні показники тих країн, в яких їх інституціональний устрій.

Все ж таки залишилось відкритим питання про критерії обрання країн для аналізу. Перш за все можна обрати країни, які конкурують між собою за критеріями престижності освіти, за якістю організації навчального процесу. Перш за все це будуть розвинені країни з високим рівнем ВВП, зокрема країни, що належать до англосаксонської CEM [6]. Для контрастного порівняння можна обрати країни, які розвиваються.

Це в свою чергу формує особливі вимоги до специфіки інститутів вищої школи і зумовлює визначення особливого і відмінного, що відрізняє iii від економічних інституціональних систем в цілому та окремих іiї складових. Це, в свою чергу, створює особливі умови до вибору методів та інструментів компаративного аналізу елементів інституціональної системи ВО. Так інституціональне забезпечення систем вищої школи у різних СЕМ та відповідна організація інституціонального забезпечення систем ВО, в якості загального, у функціональній сфері мають надання освітніх послуг. Разом з тим у відмінних національних системах ВО забезпечення виконання цієї функції може бути покладеним на специфічні організаційні форми.

Так, важливою складовою системи навчання англо-американської моделі ВО $\epsilon$ університетський кампус. Саме навколо організації життя в ньому будується весь навчальний процес. Приватне життя студента виявляється вплетеним в суспільний простір кампусу. 3 іншого боку в континентальній європейській системі, навчальні підрозділи університету можуть бути розпорошені в різних місцях. А особисте приватне життя студентів лише частково пов'язується з процесом навчання. Як це не парадоксально виглядає на перший погляд, але саме в яскраво вираженій індивідуалістичній, за соціальними орієнтаціями ціннісної системи, англо-американській моделі організації навчального процесу виховання особистих якостей студента, визнається першочерговим завданням вищої школи.
Відповідно цьому підпорядковується побудова інституціональної системи надання освітніх послуг. 3 протилежного боку узагальнена континентальна модель, в більшій мірі, в якості першочергового завдання, акцентує увагу на формування конкретно-професійних компетенцій студента. Відповідно створюється можливість більш чіткого розподілу між особистим, приватним життям студента i навчальним процесом. Організаційні форми цілком відповідають специфіці функцій і конкретних завдань, що ставляться перед системами ВО. Специфіка функцій знаходить своє відображення в інституціональних формах організації навчального процесу.

Разом 3 тим можна виділити такі загальні складові у системах ВО - основна структура (кафедри, деканати - факультет, ректорат), система фінансування, інформаційні, технічні, господарські служби.

Класичними підрозділами у структурі закладів ВО є кафедри, деканати, які об'єднуються у факультети за професійною спеціалізацією. Вони виконують відповідні завдання. Таким чином кафедра відповідає за надання професійних знань студентам; деканат - організацію навчального процесу в рамках декількох кафедр; факультет координацію кафедр та організацію навчання навчального процесу в рамках факультету; ректорат - організацію навчального процесу у закладі ВО в цілому, здійснює координацію господарської діяльності, забезпечує зовнішні зв' язки ЗВО.

За специфічне маємо організацію навчального процесу систем ВО. Відповідно кафедри можуть об'єднувати декілька напрямів в рамках однієї дисципліни. Функції деканату можуть передаватись певним інститутам, коледжам в структурі ЗВО. Таким чином функціонує американська система ВО. Відповідно одна й та ж функція забезпечується через різні організаційні форми навчального процесу. Одночасно за однією й тією ж формою організації можуть зустрічатись різні назви і навпаки, відмінні форми організації можуть носити однакову назву(інститут, коледж, деканат).

Управління закладами ВО теж є специфічним аспектом в інституціональній системі вищої школи. В свою чергу прикладом може слугувати Німеччина, де ректора, деканів, завідуючих кафедрою закладів ВО назначає держава. На відміну від цього ці посади в українській системі обираються професорсько-викладацьким складом ЗВО на загальних зборах. Таким чином у першому прикладі ми маємо справу з вираженим адміністративно-бюрократичною системою управ- 
ління ЗВО. У другому випадку до управління навчальним процесом 3ВО (принаймні формально) долучається співробітники професорськовикладацького складу навчального закладу.

Специфічним елементом інституціональної структури вищої школи $\epsilon$ фінансування. Відповідно воно може бути державним та приватним (за рахунок грантів: підприємствзамовників професійних кадрів, певних досліджень участі у наукових дослідженнях; добровільні пожертвування колишніх випускників, плата за навчання з боку студентів (американська система); доходів від цінних паперів; доходи від володіння патентами (Гарвард, Оксфорд), тощо). Наглядний приклад продемонстровано у попередньому дослідженні, де проаналізовано джерела фінансування систем
ВО різних СЕМ [6]. Як бачимо, спостерігається широкий спектр джерел фінансування ВО, в порівнянні з українською системою.

Висновки i перспективи подальших досліджень. Таким чином особливості елементів структури системи ВО зумовлюють специфіку їх компаративного аналізу. Відповідно склалися відмінні інституціональні системи ВО в англосаксонській, континентальній, далекосхідній патріархально-корпоративній та інших СЕМ. Це свідчить про відповідні відмінності у функціонуванні елементів їх інституціональних структур. В подальших дослідженнях застосування компаративного аналізу до вивчення систем ВО дозволить визначити інституціональні елементи, які можуть бути здатні забезпечити зростання ефективності вищої школи в Україні.

\section{СПИСОК ВИКОРИСТАНИХ ДЖЕРЕЛ}

1. Дюркгейм Э. О разделении общественного труда. Метод социологии // Э. Дюркгейм. - М. : Наука, 1991. $575 \mathrm{c}$.

2. Гук Л. Ретроспектива розвитку компаративістики / Л. Гук // Молодь і ринок. - 2016. - № 2. - С. 34 - 39.

3. Соколова I. Наукові підходи до проведення компаративних досліджень в освіті / I. Соколова // Методологічні засади в освітології. - 2014. - С. 23 - 29.

4. Федорова М.В. Образовательные услуги и их типология в инновационной экономике / М.В. Федорова // Проблемы современной экономики. - 2011. - №2. - С. 340 - 342.

5. Карпенко М. Новая роль высшего образования в эпоху развития инновационной экономики, глобализации И

6. Чернуха Т. Інституціональні передумови формування систем вищої освіти країн світу: порівняльний аналіз д Т. Чернуха // Науковий вісник ужгородського національного університету. Серія міжнародні економічні відносини та світове господарство. - 2018. - С. 103 - 108.

п 7. Грейф А. Институты и путь к современной экономике. Уроки средневековой торговли / А. Грейф. - М.: ஆ.Д. ВШЭ, 2013. $-536 \mathrm{c}$.

п 8. Ель Гуессаб К. Проблеми створення суспільства знань в Арабських країнах / К. Ель Гуессаб // ґॅультурологічний вісник нижньої Наддніпрянщини. - 2013. - С. 44 - 46.

л 9. Липов В.В. Институциональная комплементарность как фактор формирования социально-экономических өистем / В. Липов // Журнал институциональных исследований, 2012. - С. 25 - 43.

ц 10. Chirikov I. (2013) Universities as Knowledge Networks: The Role of Institutional Research / I. Chirikov // Studies й

и 11. Volkwein F. (2012). The Structure and Functions of Institutional Research Offices / F. Volkwein, Y Liu, J Woodell // The Handbook of Institutional Research / (eds.) R.D. Howard, G.W. McLaughlin, W.E. Knight (eds.). - San-Francisco: Hssey-Bass. - P. - 22-39.

i 12. Sharma R. (2010). Comments : Changigng Perspectives on Institutional Research. / R. Sharma. - Journal of grstitutional Research South East Asia. - № 8. - P. 6 - 7.

$\mathrm{h}$

\section{e REFERENCES}

1. Diurkheim, E. (1990). O razdelenii obshchestvennogo truda. Metod sotciologii [On the division of social labor. Sociology Method]. Moskva: Nauka [in Russian].

2. Huk, L. (2016). Retrospektyva rozvytku komparatyvistyky [Retrospective of the development of comparative studies]. Molod' i rynok - Youth and market, 2, $34-39$ [in Ukrainian].

a 3. Sokolova, I. (2014). Naukovi pidkhody do provedennia komparatyvnykh doslidzhen v osviti [Scientific approaches to conducting comparative studies in education]. Metodolohichni zasady v osvitolohii - Methodological foundations in enducation, 23 - 29 [in Ukrainian].

4. Fedorova, M.V. (2011). Obrazovatelnye uslugi i ikh tipologiia v innovatcionnoi ekonomike [Educational services and their typology in the innovation economy]. Problemy sovremennoi ekonomiki - Problems of the modern economy, 2, 340 - 342 [in Russian].

5. Karpenko, M. (2007). Novaia rol vysshego obrazovaniia v epokhu razvitiia innovatcionnoi ekonomiki, globalizatcii i depopuliatcii [New role of higher education in the era of the development of an innovative economy, 
globalization and depopulation]. Alma mater (Vestnik vysshei shkoly) - Alma Mater (High School Bulletin), №9,12 18 [in Russian].

6. Chernukha, T. (2018). Instytutsionalni peredumovy formuvannia system vyshchoi osvity krain svitu: porivnialnyi analiz [Institutional preconditions for the formation of higher education systems in the world: a comparative analysis]. Naukovyi visnyk uzhhorodskoho natsionalnoho universytetu. Seriia mizhnarodni ekonomichni vidnosyny ta svitove hospodarstvo - Scientific Bulletin of Uzhgorod National University. Series: International economic relations and world economy, 103 - 108 [in Ukrainian].

7. Hreif, A. (2013). Instituty i put k sovremennoi ekonomike. Uroki srednevekovoi torgovli [Institutes and the way to the modern economy. Lessons of medieval trade]. Moskow: I.D. VSHE [in Russian].

8. El, Huessab K. (2013). Problemy stvorennia suspilstva znan v Arabskykh krainakh [Problems of creation of a knowledge society in Arab countries]. Kulturolohichnyi visnyk nyzhnoi Naddniprianshchyny - Culturological Bulletin of Naddniprianshchyna, 44 - 46 [in Ukrainian].

9. Lipov, V.V. (2012). Institutcionalnaia komplementarnost kak faktor formirovaniia sotcialno-ekonomicheskikh sistem [Institutional complementarity as a factor in the formation of socio-economic systems]. Zhurnal institutcionalnykh issledovanii - Journal of institutional studies, 25 - 43 [in Russian].

10.Chirikov I. (2013) Universities as Knowledge Networks: The Role of Institutional Research. Studies in Higher Education, 38, 456 - 469 [in English].

11.Volkwein, F., Liu, Y., Woodell, J. (2012). The Structure and Functions of Institutional Research Offices. The Handbook of Institutional Research San-Francisco. 22 - 39 [in English].

12.Sharma, R. (2010). Comments: Changing Perspectives on Institutional Research. Journal of Institutional Research South East Asia, 8, 6-7 [in English].

Одержано 04.03.2019 